\section{Socioeconomic perspectives on violent conflict in Indonesia}

Mohammad Zulfan Tadjoeddin and Anis Chowdhury

I

donesia's post-independence history has been punctuated by internal conflicts of various kinds with varying intensity. Soon after its war of independence, a series of regional rebellions took place in the 1950s. They included armed struggles in several parts of Indonesia, aiming at the establishment of an Islamic state. The 1960s were marked by communist rebellion and anticommunist violence. President Suharto, who came to power in 1967 through a military coup that toppled President Sukarno, was able to impose a measure of peace and stability for the next three decades, although violent conflicts continued for example in Aceh, Papua, and East Timor. But the image of relative peace and stability disappeared with the fall of Suharto in 1998. More than 1,000 people were killed in a two-day anti-Chinese riot in Jakarta only a week before Suharto was removed from office. After his fall, armed separatist struggles in Aceh, Papua, and East Timor intensified. Close to 10,000 people died in interethnic violence that flared up mainly in the eastern part of the country. Routine, everyday violence also increased markedly. ${ }^{1}$ Latent conflict became open and manifested itself in civil riots among ethnic groups as well as in regional armed revolts, partly due to the legacy of the authoritarian regime. ${ }^{2}$

The rise of interethnic and center-regional conflicts as well as of routine, everyday violence coincided with Indonesia's transition to democracy. In the literature, a reasonably strong argument has been made that transition to democracy is accompanied by sociopolitical turbulence (internal conflicts), with widespread violence. In addition, the modernization hypothesis causally links income levels to democratic transition, arguing in particular that prosperity breeds democracy and not the other way around. At a low level of income, it is thought, democracy is more likely to generate regression to repression rather than to accountability (which is more likely to occur in a more affluent society and is expected to bring peace). ${ }^{3}$

The hypothesized link between democratic transition in low or middle-income countries and violence takes on an added dimension when the political transition takes place amidst market liberalization. They can be a deadly mix breeding ethnic hatred and violence. ${ }^{4}$ This occurs when the poor majority, suddenly feeling empowered due to democratization, attacks the wealthy minority that benefits from market liberalism. Thus, democratic transition may be problematic not just on its own account. Casual observations suggest examples ranging from the former Soviet Union to Rwanda, the Philippines, Venezuela, and Indonesia.

Following a synopsis of the two main current variants of conflict theories (greed and grievance), a basic categorization of violent conflict in Indonesia is presented.
The thrust of the article then examines, for the case of Indonesia, the basic conflict categories in light of the greed and grievance debate. The final section concludes.

Theoretical perspectives: greed and grievance

Much of the literature of the past 10 years has debated two possible causal attributes of violent withinstate conflict: greed and/or

grievance. According to the greed perspective, conflict reflects elite competition over valuable point-source natural resource rents, concealed with the fig leaf of collective grievance. Rebellions and civil wars are more likely to start up and endure when they are carried by natural resource-based rents or financed by sympathetic diasporas. In contrast, the grievance explanation stresses the perception of unjust treatment of people and groups that share similar identities. It can be referred to as justice-seeking motivation. Central to grievance is identity and group formation. Theories of grievance are divided into emphasizing relative deprivation, polarization, or horizontal inequality. Of course, the greed and grievance themes may be complementary rather than competitive explanations of violent intra-state conflict. ${ }^{5}$

Some categories of violent conflict in Indonesia

Indonesia experienced an outburst of violent conflict in the wake of the economic crisis of 1997-98. This was followed by the collapse of the autocratic regime of Suharto. Between 1996 and 2002, violence claimed an estimated 19,000 lives. About 9,000 of these died in secessionist violence in East Timor and Aceh, and 10,000 in ethnic strife and "routine” violence. Violent internal conflict is not new to Indonesia. Around 40,000 people were killed in the country between 1950-61 and around 500,000 to 600,000 alleged communist were murdered in the mid $1960 \mathrm{~s}$. ${ }^{6}$

The economic and social costs of these violent conflicts also were substantial. For example, while between 1999 and 2002 Indonesia experienced average annual GDP growth of four percent, the economy of Aceh province, where a secessionist rebellion was active, contracted by 2.3 percent annually and its poverty rate doubled from 14.7 to 29.8 percent. The within-Indonesian Human Development Index (HDI) ranking for ethnic strife-ridden Ambon declined from third in 1999 to twenty-ninth in $2002 .{ }^{7}$ From 1999 to 2000, the ethnic conflict-torn districts of Central Maluku and Southeast Maluku saw their regional GDPs drop by 22 and 40 percent, respectively. The only plausible explanation for these declines, while the country as a whole was recovering, 
is religion-based violent conflict between Christians and Muslims.

In addition to high-profile violence such as separatist, ethnic, and religious affiliation-based conflict, Indonesia also experienced "low intensity" violence, centered around sporadic group brawls and vigilantism. These kinds of violence tend to generate low numbers of casualties per event and happen in more "routine, everyday" fashion (hereafter referred to as routine violence). They usually cause little economic damage.

Another kind of conflict occurs when, without a distinct separatist agenda, a community is unhappy with the State, for whatever reason. ${ }^{8}$ This may become manifest for example in initially peaceful protests and strikes. But a number of factors, such as unruly protest behavior, overzealous law-enforcement authorities, or counter-protests by government supporters, can trigger violence. Conflict also involves community against business enterprises over the use of local resources and opportunities. This happened mostly in extractive industries; one much publicized incident involved a multinational mining company (Freeport) in the province of Papua. $^{9}$

This article examines three categories of conflict: first, separatist violence; second, ethnic/sectarian violence; and third, routine violence. The other two (community versus state, and community versus companies) are left out either because of insufficient data or because they do not show a clear enough pattern to extract reliable generalizations.

For clarity, we define our three categories of conflict as follows. First, secessionist conflict refers to conflict between the central government and regions wanting to secede from the federation or at least having some degree of secessionist aspirations. This is also labeled as center-regional conflict and is "vertical” in nature. Second, ethnic violence is the conflict between different ethnic groups without any formal state involvement and is not directed against the state; it is "horizontal" in nature. Third, routine violence is the residual of the first two and centers on group brawls and vigilantism. These three are examined in the next section.

\section{The case of Indonesia}

Center-regional conflict

The focus here is on the troubled relation between the central government and four regions rich in natural resources: Aceh, Papua, Riau, and East Kalimantan. ${ }^{10}$ To varying degrees, each has posed a secessionist challenge to the central government. Levels of conflict in these regions differ considerably from each other. Aceh has had the highest level of conflict, in part because both political and military wings of the rebel organization have been active for about three decades (since 1976). According to the internationally agreed definition, it is a clear case of a civil war. ${ }^{11}$ It ended in 2005 when the Helsinki accord between the Government of Indonesia and the Free
Table 1: Characteristics of four resource-rich Indonesian regions

\begin{tabular}{|c|c|c|c|}
\hline Province & $\begin{array}{l}\text { Main } \\
\text { resources }\end{array}$ & $\begin{array}{l}\text { Conflict } \\
\text { level }\end{array}$ & $\begin{array}{l}\text { Conflict } \\
\text { manifestation }\end{array}$ \\
\hline Aceh & $\begin{array}{l}\text { natural gas, } \\
\text { timber }\end{array}$ & high & $\begin{array}{l}\text { well-articulated, secessionist } \\
\text { movement; significant, violent } \\
\text { insurgency by an organized rebel } \\
\text { group (GAM) }\end{array}$ \\
\hline Papua & $\begin{array}{l}\text { oil, copper, } \\
\text { natural gas, } \\
\text { gold, timber }\end{array}$ & medium & $\begin{array}{l}\text { fragmented, poorly-articulated } \\
\text { secessionist, political movement; } \\
\text { minor, violent insurgency by a } \\
\text { less-well organized group (OPM) }\end{array}$ \\
\hline Riau & $\begin{array}{l}\text { oil, timber } \\
\text { natural gas, } \\
\text { minerals }\end{array}$ & low & $\begin{array}{l}\text { minor political secessionist } \\
\text { sentiment }\end{array}$ \\
\hline $\begin{array}{l}\text { East } \\
\text { Kalimantan }\end{array}$ & $\begin{array}{l}\text { oil, timber } \\
\text { natural gas, } \\
\text { minerals }\end{array}$ & low & $\begin{array}{l}\text { minor political secessionist } \\
\text { sentiment }\end{array}$ \\
\hline
\end{tabular}

Aceh Movement (GAM) was agreed. Since then, Aceh has been recovering and rebuilding its socioeconomic and political life under the so-called self-government provision.

The Papuan conflict could be considered an intermediate case. Although both political and military wings of rebel groups are active there, no civil war, according to the commonly agreed definition, has occurred. Compared with Aceh, Papua's secessionist movement has been significantly weaker. It is fragmented and less organized, partly because it has to deal with animosities among hundreds of tribal groups, and because it neither has charismatic leaders to unite the community (like Hasan Tiro or Daud Beureuh in Aceh) nor a strong diaspora community to provide support. Its military wing Organisasi Papua Merdeka (OPM, or Free Papua Organization) has only been able to launch sporadic violence directed against the Indonesian army or police, foreign companies, and migrant groups. The 1998 democratic transition in Indonesia provided momentum for renewed secessionist demands from the province and culminated in the second Papuan People Congress in 2000. The Congress openly demanded an independent Papua, separate from Indonesia, through peaceful and democratic means. The province was granted special 
autonomy status in 2001 and since then the once popular call for independence, although not extinguished, has diminished significantly.

The center-regional conflicts in Riau and East Kalimantan can be considered as minor because no rebel groups exist and only relatively minor secessionist sentiments have been put forward. The second Riau People's Congress (KKR, or Kongres Rakyat Riau) held in Pekan Baru, January 2000, issued a decree calling for Riau independence, separate from Indonesia. In a roughly similar tone, in November 1999, the provincial parliament of East Kalimantan officially issued a decree (No. 28/1999) demanding federal state status from Indonesia. The demands from these two regions were the climax of growing secessionist sentiments in the regions following the fall of Suharto in mid-1998. Conflict and other characteristics of the four provinces are summarized in Table 1.

Subnational entities reacted to the centralistic nature of the New Order government in three ways. First, the industrialized resource-poor Java region enjoyed benefits during the New Order authoritarian past as in Suharto's New Order regime, the idea of power was very much derived from Javanese culture of paternalistic relationships. Second, non-Javanese resource-poor regions felt unhappy with the centralistic and autocratic style of the regime but acknowledged that they benefitted from central government subsidies. Third, non-Javanese resource-rich regions felt unjustly treated because they were subsidizing the New Order's equalization policy scheme without having much political say in the center.

To face grievances, the center had available a range of policy options and instruments. They included the implementation of the equalization policy with suppression, offering transfers or subsidies, sharing resource rents, or a combination of these three. Overt armed rebellion was an extreme form of noncooperative bargaining and a clear case of social contract failure, akin to what Hirshleifer called the vertical social contract. In strategic game-theoretic terms, one could say that the lack of credibility of the central government policies or its new initiatives toward the regions contributed to this social contract failure and fostered the continuation of secessionist conflicts, particularly in Aceh. ${ }^{12}$ But explaining the continuation of center-region conflicts in Indonesia during the Suharto era and thereafter is different from explaining their onset. The separatist movement in the resource-rich provinces was triggered by socioeconomic grievances. In particular, socioeconomic grievances arise from the phenomenon of "aspiration to inequality."13 This refers to demands by the rich regions for a degree of community welfare that would correspond to their relatively high regional prosperity due to natural resource endowments, a situation that could be phrased as "the rage of the potentially rich.” It reflects regional protests against the central government's equalization scheme by distributing resource-rents across the whole of the nation.

Regional prosperity may or may not result in community welfare. The difference between the two therefore has to be highlighted. The former refers to regional output measured solely by GDP. This calculates value-added in monetary terms derived from
Table 2: Regional prosperity and community welfare (Indonesia $=100)$

\begin{tabular}{|c|c|c|c|c|c|}
\hline \multirow{2}{*}{$\begin{array}{l}\text { Provinces } \\
\text { (resource-rich } \\
\text { districts) }\end{array}$} & \multirow{2}{*}{$\begin{array}{l}G D P \\
\text { per cap. } \\
1996\end{array}$} & \multirow{2}{*}{$\begin{array}{l}\text { Purchasing } \\
\text { power } \\
1996\end{array}$} & \multicolumn{2}{|c|}{$\begin{array}{l}\text { Poverty } \\
\text { headcount }\end{array}$} & \multirow{2}{*}{$\begin{array}{l}\text { Human } \\
\text { development } \\
\text { index } 1996\end{array}$} \\
\hline & & & 1996 & 1999 & \\
\hline Aceh & 142 & 98 & 72 & 63 & 102 \\
\hline (Aceh Utara) & 350 & 96 & 87 & 75 & 103 \\
\hline Papua & 170 & 97 & 241 & 234 & 89 \\
\hline (Fak-Fak) & 1,616 & 92 & 278 & 242 & 97 \\
\hline Riau & 241 & 99 & 72 & 60 & 104 \\
\hline (Bengkalis) & 435 & 97 & 77 & 74 & 103 \\
\hline (Kepulauan Riau) & 283 & 96 & 54 & 42 & 101 \\
\hline East Kalimantan & 404 & 100 & 55 & 86 & 105 \\
\hline $\begin{array}{l}\text { Resource-poor } \\
\text { non-Javanese provi }\end{array}$ & $\begin{array}{r}71 \\
\text { vinces }\end{array}$ & 99 & 118 & 104 & 99 \\
\hline $\begin{array}{l}\text { Java provinces } \\
\text { (excluding Jakarta) }\end{array}$ & a) 80 & 102 & 104 & 111 & 101 \\
\hline
\end{tabular}

Note: The first numeric column is a measure of regional prosperity; the others reflect community welfare. Purchasing power is based on household expenditure data (National Socioeconomic Survey, SUSENAS).

Source: Authors' calculation based on BPS-Statistic Indonesia data.

a region or geographical unit (district, province, or country) in some accounting period, usually one calendar year. The latter refers to indicators of physical well-being of the people living in the region. Measures of community welfare include consumption expenditure and indicators such as of health, education, and poverty, in short, human development measures.

Levels of interregional income (regional GDP) inequality have been substantial, mainly because oil, gas, and key minerals are concentrated in only a few regions of Indonesia. But in terms of community welfare, interregional inequality has been extremely low, and this is due to the success of the New Order equalization policies. ${ }^{14}$ According to a measure of interdistrict inequality (the L-index), regional output inequality (based on GDP) is almost four times higher than is regional expenditure 
inequality (based on a consumption survey measure). This contrasts, for example, with Indonesia's neighbor Thailand, where the L-index figure suggests virtually no correlation across regions between community welfare indicators and the regional prosperity measure. ${ }^{15}$

Table 2 suggests the relative success of the equalization campaign. In GDP per capita terms, the resource-rich regions stack up very well relative to the country as a whole. Yet welfare measures such as purchasing power and human development are not significantly different from the national average or from the non-resource Java and non-Javanese provinces. Only Papua lagged behind the nation as well as the other provinces.

"Aspirations to inequality" are a response to people’s first-hand experience of their community welfare being reduced to, or even below, the national average, even though their regions are rich in natural resources. While this shows the success of the equalization scheme, the resource-rich provinces felt that they had been robbed. They expected their welfare level to match their wealth (resources), hence their rage against the center or their aspiration to inequality. ${ }^{16}$ This was especially so as the equalization scheme was designed and implemented unilaterally by a Javanese ruler and they had no say in it.

This "rage" was aggravated by visible relative deprivation of the native population, often engineered by the central government. For example, Javanese migrants outnumbered Acehnese in top-strata jobs (government officials, professionals, and technicians) as well as in land holding compared with native Bataks vis-à-vis Javanese migrants in the neighboring province of North Sumatra. In fact, migrant Javanese have become the second-largest ethnic group in both provinces. The government's transmigration policy played a large role in this shift in the ethnic mix. Relative deprivation of the native population vis-à-vis migrants is also evident in Papua. In 1971, native Papuans accounted for 96 percent of the province's population; by 2005 this had been reduced to 59 percent. The remainder are migrants originating from government-sponsored transmigration and voluntary in-migration. Migrants dominate the urban economic sectors and the more productive agricultural activities, while the majority of native Papuans are stuck in the traditional extractive sectors. ${ }^{17}$

Decentralization policies have been effective in dealing with secessionist demands in these resource-rich provinces. The 2001 Special Autonomy Law for Papua has calmed the separatist movement. The provinces of Riau and East Kalimantan that posed strong demands for autonomy have been happy with the two decentralization laws passed in 1999 and their subsequent 2004 revisions. Aceh has been an exception. Having experienced violence for a longer time period, and seeing the central government failing to deliver on promises, earlier decentralization laws did not curb the separatist conflict. For Aceh, the credibility of the central government's policy was at issue. But it seems that the Helsinki agreement between the government and GAM is viewed as credible; it needed a popularly elected President to generate sufficient good-will. Since the signing of the Helsinki agreement, the peace has held. ${ }^{18}$
Table 3: Major episodes of ethnic violence in Indonesia

\begin{tabular}{|c|c|c|c|c|}
\hline $\begin{array}{l}\text { Main } \\
\text { cleavage }\end{array}$ & Provinces & $\begin{array}{l}\text { Affected } \\
\text { districts }\end{array}$ & $\begin{array}{l}\text { Time- } \\
\text { span }\end{array}$ & $\begin{array}{l}\text { Estimated } \\
\text { casualties }\end{array}$ \\
\hline $\begin{array}{l}\text { Dayak- } \\
\text { Madurese }\end{array}$ & $\begin{array}{l}\text { West } \\
\text { Kalimantan }\end{array}$ & $\begin{array}{l}\text { Bengkayang, } \\
\text { Pontianak, Landak, } \\
\text { Sambas, Sanggau }\end{array}$ & $\begin{array}{l}30 \text { Dec } 1996 \text { - } \\
28 \text { Feb } 1997\end{array}$ & 1,006 \\
\hline $\begin{array}{l}\text { Malay- } \\
\text { Madurese }\end{array}$ & $\begin{array}{l}\text { West- } \\
\text { Kalimantan }\end{array}$ & $\begin{array}{l}\text { Bengkayang, } \\
\text { Sambas }\end{array}$ & $\begin{array}{l}\text { 19 Jan to } 26 \\
\text { Apr } 1999\end{array}$ & 481 \\
\hline $\begin{array}{l}\text { Dayak- } \\
\text { Madurese }\end{array}$ & $\begin{array}{l}\text { Central } \\
\text { Kalimantan }\end{array}$ & $\begin{array}{l}\text { Kotawaringin Timur, } \\
\text { Kotawaringin Barat, } \\
\text { Kapuas, } \\
\text { Palangkaraya }\end{array}$ & $\begin{array}{l}2 \text { Dec } 2000 \text { - } \\
6 \text { July 2001* }\end{array}$ & 1,255 \\
\hline $\begin{array}{l}\text { Christian- } \\
\text { Muslim }\end{array}$ & Maluku & $\begin{array}{l}\text { Ambon, Maluku, } \\
\text { Tengah, Maluku } \\
\text { Tenggara, Buru }\end{array}$ & $\begin{array}{l}15 \text { Jan } 1999 \text { - } \\
2 \text { Nov } 2002\end{array}$ & 2,023 \\
\hline $\begin{array}{l}\text { Christian- } \\
\text { Muslim }\end{array}$ & $\begin{array}{l}\text { North- } \\
\text { Maluku }\end{array}$ & $\begin{array}{l}\text { Ternate, Tirode, } \\
\text { all Halmahera }\end{array}$ & $\begin{array}{l}19 \text { Aug } 1999 \text { - } \\
7 \text { Dec } 2000\end{array}$ & 2,782 \\
\hline $\begin{array}{l}\text { Christian- } \\
\text { Muslim }\end{array}$ & $\begin{array}{l}\text { Central } \\
\text { Sulawesi }\end{array}$ & Poso & $\begin{array}{l}\text { Apr - July } \\
2000\end{array}$ & 613 \\
\hline $\begin{array}{l}\text { Anti- } \\
\text { Chinese }\end{array}$ & Jakarta & & May 1998 & 1,206 \\
\hline $\begin{array}{l}\text { Anti- } \\
\text { Chinese }\end{array}$ & $\begin{array}{l}\text { Central } \\
\text { Java }\end{array}$ & Solo & May 1998 & 33 \\
\hline \multicolumn{4}{|c|}{ Total number of deaths } & 9,399 \\
\hline
\end{tabular}




\section{Ethnic strife}

From 1996 to 2000, various parts of Indonesia experienced a surge of ethnic violence (see Table 3), especially between the collapse of the New Order in mid-1998 and the full implementation of regional autonomy (decentralization) in 2001. ${ }^{19}$

Excluding the episodes of anti-Chinese violence that took place primarily in Jakarta, the national capital, and in Solo in Central Java (the hometown of Suharto's wife) a few days before Suharto's fall in May 1998, the other major episodes of ethnic violence have been referred to as "small town wars." The ethnic, small-town warfare episodes outside Java, and in eastern Indonesia in particular, were led by urban middle-class elements. These small towns and regions were particularly dependent on central government subsidies The ratio of civil servant to nonagricultural workers has been interpreted as measuring the degree of local reliance on state resources. Indeed, high ratios are found for four provinces (West and Central Kalimantan, Central Sulawesi, and Maluku) where major ethnic strife occurred. Thus, limited economic options in the nonstate-sector may render a region more vulnerable to interethnic competition. $^{20}$

The explosion of ethnic violence coincided with the decentralization reforms of 1999-2000. This may be viewed as a moment of opportunity for local actors to take control of the political and financial resources expected soon to be transferred to local entities under the decentralization scheme. Therefore, the move toward decentralization would significantly inflate the expected benefits of controlling local power, over which conflict and violence would be highly possible. The expected gains from conflict arise either from increasing returns to fighting efforts or from the elimination or conquest of the opponents. ${ }^{21}$ This analysis corresponds closely to the greed hypothesis of conflict. ${ }^{22}$

In some cases, interethnic violence goes beyond spontaneous intergroup clashes or ethnic riots, taking the form of serious interethnic warfare. It can spread to a wider geographic area and penetrate deep into the interior, as in the case of the episodes of Dayak-Madurese violence in Kalimantan and Christian-Muslim clashes in Maluku and Sulawesi. Some authors have labeled these as communal war, not simply ethnic violence. For various reasons, in communal war, formal state authority (the police and the military) often has no role to play. On occasion, elements of state authority, motivated by ethnic loyalty, may take sides with the warring parties, leaving behind their formal duty to maintain law and order. Such a situation can be described as anarchy. $^{23}$

An alternative, and perhaps superior, explanation for ethnic or communal violent conflict during the post-Suharto transition period may be offered by the grievance rather than the greed hypothesis. ${ }^{24}$ Yet the origin of violence may not lie in the widening of opportunities (horizontal inequality) but in the narrowing of inequality. A previously privileged ethnic group may feel aggrieved when it loses position relative to another group; groups may tend to fight when they become more equal. ${ }^{25}$
As we have seen, three decades of development during the Suharto era brought economic and social dislocations for certain groups and resulted in significantly diminished relative positions vis-à-vis others, such as in the case of Dayaks in Kalimantan. ${ }^{26}$ Power loss-related grievance by the relatively rich is a new interpretation of horizontal inequality: it is "the rage of the previously rich."27

Due to the convergence of socioeconomic conditions, econometric work cannot find convincing horizontal inequality-related evidence for deadly ethnic violence in Indonesia. In one work, for instance, cross-district logistic regressions suggest only child mortality as a statistically significant factor associated with deadly ethnic strife. Other measures of group horizontal inequality such as income, education, land holding, young male unemployment, and government employment did not result in statistically significant effects on ethnic violence. ${ }^{28}$ These results have little intuitive appeal; it is hard to believe that child mortality differences between groups can be instrumentally used by ethnic elites to mobilize coethnics.

In contrast, in a two-stage regression approach using district-level data, another study finds that ethnic strife is rooted in relative deprivation-related grievance of local educated, but still poor communities. However, this then mutates into local elites' greed as they compete for political power at the local level, due to high local dependency on state resources. This suggests that greed and grievance are mutual, and inseparable, explanations of conflict. ${ }^{29}$

In the first-stage regression, it is found that districts experience more severe ethnic strife with higher poverty, both in terms of consumption poverty (headcount ratio) and capability poverty (human poverty index), even as they achieve higher levels of education (years of schooling). The finding is robust when taking differences between rural and urban districts and between Java and non-Java, into account. It points to the existence of an expectations gap between actual welfare and higher future welfare expected on account of higher education. The second-stage regression finds a positive and statistically significant relationship between local-level budget allocation by the central government and the severity of violence. After decentralization, budget allocations were increased (in relative terms) to regions that experienced more severe ethnic strife. Regions with severe ethnic strife became more reliant on state resources at the local level, and the state at the local level became a "prize" to compete for. This can be qualitatively linked to the local level political setting in post-ethnic strife periods as the relative bargaining power of ethnic groups changed. In some cases groups have succeeded in turning the clock back, for example Christians in Maluku and Dayaks in Kalimantan. The relative importance of the size of the state at the local level would therefore seem to matter. Rent-seeking reflects greed and can take on violent forms.

\section{Routine violence}

Routine group violence is differentiated from separatist and ethnic violence in that it 
Table 4: Routine violence in four Javanese provinces* (1994-2003)

\begin{tabular}{|c|c|c|c|c|c|}
\hline \multirow[b]{2}{*}{ Categories } & \multicolumn{2}{|c|}{ Incidents } & \multicolumn{2}{|c|}{ Deaths } & \multirow{2}{*}{$\begin{array}{l}\text { Deaths per } \\
10 \text { incidents }\end{array}$} \\
\hline & Total & $\%$ & Total & $\%$ & \\
\hline a. Popular justice/vigilante & 592 & 30.3 & 373 & 59.6 & 6.3 \\
\hline b. Group brawls & 516 & 26.4 & 174 & 27.8 & 3.4 \\
\hline c. State-Community & 244 & 12.5 & 27 & 4.3 & 1.1 \\
\hline d. Political party \& factions & 227 & 11.6 & 19 & 3.0 & 0.8 \\
\hline e. Economic & 323 & 16.5 & 19 & 3.0 & 0.6 \\
\hline f. Others & 52 & 2.7 & 14 & 2.2 & 2.7 \\
\hline Total & 1,954 & 100.0 & 626 & 100.0 & 3.2 \\
\hline
\end{tabular}

Notes: * The provinces are Banten, and West, Central, and East Java. They account for 90 percent of Java's population. (The two Javanese provinces remaining provinces are the Jakarta and Yogyakarta.)

Source: Calculated from the UNSFIR conflict database.

usually occurs episodically. ${ }^{30}$ It is treated as the residual, after the other forms of violence have been accounted for. Routine violence centers on vigilante violence or popular justice, and intergroup or neighborhood brawls (see Table 4). ${ }^{31}$ Our focus so far has been directed at higher-profile and lethal episodic kinds of incidents that exclusively take place in the form of ethno-communal and separatist violence in the outer islands. In contrast, the low-profile and low-intensity routine kind of violence is most common in Java. Rarely does it produce headlines. Incidents are not reported beyond the local newspapers, unless they turn very ugly. This sort of violence has attracted minimal attention from either researchers or policymakers.

Routine violence is closely linked to widespread social frustration, for example resulting from weak law and order as in the case of popular justice. It might be caused by socioeconomic declines and lower levels of human development and both are likely to create a situation where the opportunity cost of engaging in violence is extremely low. This encourages people — especially unemployed youth — to participate in violence. Routine violence can also be linked to relative deprivation as in the case of the rising segment of an inverted U-shaped relation between education and routine: at relatively low levels of education, violence tends to rise, and with higher levels of education, violence tends to fall. ${ }^{32}$ (The increase in income levels might have lagged behind expectations commensurate with increased education levels.) Another possibility is that the increase in education from a very low level might change society to become more dynamic and increase its ability to express dissatisfaction. This, in turn, might result in higher levels of violence until it reaches the turning point. Falling violence at higher levels of income reflects that the opportunity cost of engaging in violence could be high; therefore violence declines.

In the long run, routine violence will decline as society becomes more developed with higher income, education, and overall levels of human development. Such a situation would transform into a stronger state, advance law and order, and in general lead to better institutions.

\section{Conclusion}

Early conflict studies in Indonesia were dominated by detailed ethnographic accounts of conflict episodes and sociopolitical and historical perspectives thereon. They have not emphasized socioeconomic perspectives. Several studies have emerged lately that point to the important role of socioeconomic factors. In particular, grievances due to relative deprivation, horizontal inequality, and marginalization can act as conflict drivers. The greed hypothesis of conflict in natural resource-rich regions does not appear to be as strong an explanation.

\section{Notes}

Mohammad Zulfan Tadjoeddin, the corresponding author, is a doctoral candidate at the University of Western Sydney, Australia, and visiting researcher at the Institute of Social Studies (ISS), the Netherlands. He may be reached at z.tadjoeddin@uws.edu.au. Anis Chowdhury is professor of economics at the University of Western Sydney, Australia. His address is a.chowdhury@uws.edu.edu.

1. See Tadjoeddin (2002); Varshney, Tadjoeddin, and Panggabean (2008).

\section{Bertrand (2004).}

3. Literature: See, e.g., Huntington (1968); Snyder (2000); Hegre, Ellingsen, Gates, and Gleditsch (2001). Also see Collier and Rohner (2008) for theoretical and empirical findings on democratic transition and violence in poor and lower middle income countries. Modernization: due to Lipset (1959).

\section{Chua (2002)}

5. Greed: Collier, et. al. (2003); Collier and Hoeffler (2004; Collier (2007). Grievance: Stewart (2000; 2008); Gurr (1970); Montalvo and Reynal-Querol (2005). Complementary: e.g., Murshed and Tadjoeddin (2008) and Murshed (this issue). 
(C) www.epsjournal.org.uk - Vol. 4, No. 1 (2009)

6. 1996-2002: Klinken (2007); Varshney, et al. (2008). 40,000: PRIO-Uppsala conflict database); communists: Sulistyo (2000). The post-independence conflicts in Indonesia between 1945 and the mid-1960s were mostly revolutionary affairs when conflicting groups were negotiating what kind of nation-state they were going to have. In contrast, conflicts during Suharto's military-backed "New Order” authoritarian regime (mid-1960s until the late 1990s) were dominated by state-sponsored violence as a means of repression (Anderson, 2001).

7. Human Development Index: see UNDP, BPS, and BAPPENAS (2004).

8. The reasons may vary from a local issue, such as a development project or the disapproval of a local official to a national issue such as a new regulation or law perceived to be unfair.

9. For a comprehensive discussion of different kinds of conflict in Indonesia, see Tadjoeddin (2002).

10. East Timor is not included, as it has not been part of Indonesia since the 1999 U.N.-organized referendum. It also has a distinctly different history as it was colonized by Portugal, while the rest of Indonesia was under the Dutch rule.

11. Civil war, according to the definition commonly agreed by scholars in the field, takes place when an identifiable rebel organization challenges the government militarily and the resulting violence results in more than 1,000 combat-related deaths, with at least 5 percent on each side (Collier, et al., 2003).

12. Vertical social contract: Hishleifer (1995); game-theory model: see Addison and Murshed's (2001).

\section{See Tadjoeddin, et al. (2001).}

14. Under a centralized system, the central government collected all revenues from natural resources and distributed them across all regions, mainly in the form of agricultural development and social expenditure such as basic education and health. The guiding principle for fiscal distribution was the welfare of all Indonesians; the regions which were behind in social development received more, especially through discretionary Presidential allocations, known as Inpres.

15. See Tadjoeddin, et al. (2001).
16. In the case of Aceh, Dawood and Sjafrizal (1989) had put forward a similar concern nearly two decades ago. Although by 1985 Aceh, together with Riau and East Kalimantan, had been the largest three provinces contributing to Indonesian exports. Aceh's “benefits to [the] local economy have been much smaller and [the] cost-benefit calculus more problematic, perhaps ironically one of the most staunchly independent regions, long in conflict with the central government, is now subsidizing that government and the rest of the country” (p. 115).

17. North Sumatra: see Brown (2005); Papuan ethnic mix: Elmslie (2008); Papuan economic activity: McGibbon (2004).

18. Effective: Tadjoeddin (2007). Law: Furthermore, the 2006 direct elections for the Papuan governor opened intra-provincial divisions along political and subregional factional affiliations and weakened separatist sentiments (Mietzner, 2006). The separatist sentiment is, however, still there, although only in muted form. Aceh: After the 2004 devastation caused by the tsunami, separatist leaders realized the difficulties of continuing the conflict. The relief and recovery work jointly done by the rebels and the military also helped built trust.

19. The UNSFIR conflict database for Indonesia is constructed based on leading provincial newspapers and complemented with any available information, case studies, and consultation with knowledgeable sources at local the level (see Varshney, et al., 2008).

20. See Klinken (2007). In 1990, the North Maluku province was part of Maluku.

21. Return to fighting: Hirshleifer (1995); conquering opponents: Skaperdas (2002).

\section{See Klinken (2007).}

23. Communal war: Tomagola (2000); Klinken (2007); anarchy: Hirshleifer (1995). Interestingly, since the introduction of decentralization some kind of con-sociational political arrangements at the local has emerged in regions that previously experienced severe ethnic violence. For example, in direct elections it has became a common practice for candidates from previously warring ethnic groups to team up on the same ticket to campaign for head and deputy-head of local executive political office. Thus, after anarchy, previously warring parties have been able to cooperate. This is an indication of some sort of horizontal social contract emerging.

24. Grievance: Steward (2000); greed: Collier and Hoeffler (2004). 
(C) www.epsjournal.org.uk - Vol. 4, No. 1 (2009)

25. Horizontal inequality: see Stewart (2000). For such an explanation of ChristianMuslim violence in the Malukus and Sulawesi, see Klinken (2007), Bertrand (2002; 2004), and Aragon (2001). Also see Besancon (2005).

26. See Klinken (2007); Davidson (2008); Peluso and Harwell (2001). Interestingly, changes in the relative position of various ethno-religious groups did not result in the widening of inequality among them. Instead, in most cases the development policies of Suharto's New Order government caused convergence of socioeconomic conditions of different ethno-religious groups; see Tadjoeddin (2003).

27. The logic of "the rage of the rich" is also applicable to the case of secessionist sentiments posed by several resource-rich provinces in Indonesia (see the previous subsection). In a way, the aspiration to inequality can be regarded as the rage of the rich.

\section{Mancini (2008).}

29. Tadjoeddin (2008).

30. For the Indonesian context, the phrase was introduced by Varshney, et al. (2008); also see Tadjoeddin and Murshed (2007).

31. The classes in Table 4 are based on Varshney, et al. (2008) and are mutually exclusive, but they can be criticized for using inconsistent bases. Categories (a) and (b) concern forms of violence along intercommunal lines but do not involve ethnic dimensions (otherwise we would call them ethnic violence). Neither do they occur along the lines of categories (c), (d), or (e). Category (c) is based on the statecommunity cleavage; categories (d) and (e) are similar to (a) and (b). However, if we just universally apply the form-based categorization, all categories take the form of either popular justice/vigilante violence or group brawls without involving ethnic dimensions.

32. Frustration: Welsh (2008); education: Tadjoeddin and Murshed (2007).

\section{References}

Addison, T and S.M. Murshed. 2001. "From Conflict to Reconstruction: Reviving the Social Contract.” UNU/WIDER Discussion Paper 48. Helsinki: UNU/WIDER.

Anderson, B., ed. 2001. Violence and the State in Suharto's Indonesia. Southeast Asia Program. Ithaca, NY: Cornell University.

Bertrand, J. 2002. "Legacies of the authoritarian past: religious violence in Indonesia’s Moluccan islands.” Pacific Affairs, Vol. 75, pp. 57-86.
Bertrand, J. 2004. Nationalism and Ethnic Conflict in Indonesia. Cambridge, UK: Cambridge University Press.

Chua, A. 2002. World on Fire: How Exporting Free Market Democracy Breeds Ethnic Hatred and Global Instability. New York: Doubleday.

Collier, P. 2007. The Bottom Billion. Oxford, UK: Oxford University Press.

Collier, P. and A. Hoeffler. 2004. "Greed and Grievance in Civil Wars." Oxford Economic Papers, Vol. 56, No. 4, pp. 563-595.

Collier, P. and D. Rohner. 2008. “Democracy, Development and Conflict.” Journal of the European Economic Association (forthcoming).

Collier, P., L. Elliot, H. Hegre, A., Hoeffler, M. Reynal-Querol, and N. Sambanis. 2003. Breaking the Conflict Trap: Civil War and Development Policy. Oxford, UK: Oxford University Press.

Dawood, Dayan and Sjafrizal. 1989. "Aceh: The LNG Boom and Enclave Development," in H. Hill, ed. Unity and Diversity: Regional Economic Development in Indonesia Since 1970. Oxford, UK: Oxford University Press.

Davidson, J.S. 2008. From Rebellion to Riots: Collective Violence on Indonesian Borneo. Madison, WI: University of Wisconsin Press.

Elmslie, J. 2008. “Demographic Transition in West Papua and Claims of Genocide.” West Papua Project, University of Sydney.

Hegre, H., T. Ellingsen, S. Gates, and N.P. Gleditsch. 2001. "Towards a Democratic Civil Peace? Democracy, Civil Change, and Civil War 1816-1992.” American Political Science Review, Vol. 95, No., 1, pp. 17-33.

Hirshleifer, J. 1995. “Anarchy and its Breakdown.” Journal of Political Economy, Vol. 103, No. 1, pp. 26-52.

Huntington, S.P. 1968. Political Order in Changing Societies. New Haven, CT: Yale University Press.

Klinken, G.v. 2007. Communal Violence and Democratization in Indonesia: Small Town Wars. London: Routledge.

Lipset, S.M. 1959. "Some Social Requisites of Democracy: Economic Development and Political Legitimacy.” American Political Science Review, Vol. 53, No. 1, pp. 69-105.

Mancini, L. 2008. "Horizontal Inequality and Communal Violence: Evidence from Indonesian Districts,” in F. Stewart, ed. Horizontal Inequalities and Conflict: Understanding Group Violence in Multiethnic Societies. London: Palgrave Macmillan.

McGibbon, R. 2004. "Plural Society in Peril: Migration, Economic Change, and the Papua Conflict.” Policy Studies 13, Washington, D.C.: East-West Center.

Mietzner, M. 2006. “Autonomy, Democracy and Internal Conflict: The 2006 Gubernatorial Elections in Papua.” Seminar presentation, RSPAS, Australian National University, 15 May.

Montalvo, J.G. and M. Reynal-Querol. 2005. "Ethnic Polarization, Potential Conflict, and Civil Wars.” American Economic Review, Vol. 95, No. 3, pp. 796-816. 
Peluso, N.L. and E. Harwell. 2001. "Territory, Custom, and the Cultural Politics of Ethnic War in West Kalimantan Indonesia,” in N.L. Peluso and M. Watts, eds. Violent Environments. Ithaca, NY: Cornell University Press.

Skaperdas, S. 2002. “Warlord Competition.” Journal of Peace Research, Vol. 39, No. 4, pp. 435-446.

Stewart, F. 2000. “Crisis Prevention: Tackling Horizontal Inequalities.” Oxford Development Studies, Vol. 28, No. 3, pp. 245-262.

Stewart, F., ed. 2008. Horizontal Inequalities and Conflict: Understanding Group Violence in Multiethnic Societies. London: Palgrave Macmillan.

Sulistyo, H. 2000. "Palu Arit di Ladang Tebu: Sejarah pembantaian massal yang terlupakan, Jombang-Kediri 1965-66.” Jakarta: Gramedia.

Tadjoeddin, M.Z. 2002. "Anatomy of Social Violence in the Context of Transition: The Case of Indonesia 1990-2001.” Politics Administration and Change, Vol. 38, pp. 1-35.

Tadjoeddin, M.Z. 2003. "Communal Conflicts and Horizontal Inequalities in Indonesia: Dynamics and Consequences.” Presentation at the IPSK-CNRS Group Meeting on Conflict, LIPI Jakarta, 15 January.

Tadjoeddin, M.Z. 2007. “A Future Resource Curse in Indonesia: The Political Economy of Natural Resources, Conflict and Development.” CRISE Working Paper 35, University of Oxford.

Tadjoeddin, M.Z. 2008. "Educated but Poor: Localized Ethnic Violence during Transition in Indonesia." Paper accepted for presentation at the International Studies Association (ISA) Annual Conference, New York, 15-19 February 2009.

Tadjoeddin, M.Z. and S.M. Murshed. 2007. "Socio-Economic Determinants of Everyday Violence in Indonesia: An Empirical Investigation of Javanese Districts, 1994-2003.” Journal of Peace Research, Vol. 44, No. 6, pp. 689-709.

Tadjoeddin, M.Z., W.I. Suharyo, and S. Mishra. 2001. "Regional Disparity and Vertical Conflicts in Indonesia.” Journal of the Asia Pacific Economy, Vol. 6, No. 3, pp. 283-304.

Tomagola, T.A. 2000. “The Bleeding Halmahera of North Moluccas," in O. Törnquist, ed. Political Violence: Indonesia and India in Comparative Perspective. Center for Development and the Environment. Oslo: University of Oslo.

UNDP, BPS, and BAPPENAS. 2004. “Indonesia National Human Development Report 2004: The Economics of Democracy, Financing Human Development in Indonesia.” Jakarta.

Varshney, A., M.Z. Tadjoeddin, and R. Panggabean. 2008. "Creating Datasets in Information-Poor Environments: Patterns of Collective Violence in Indonesia (1990-2003).” Journal of East Asian Studies, Vol. 8, No. 3, pp. 361-394.

Welsh, B. 2008. "Local and National: Keroyokan Mobbing in Indonesia.” Journal of East Asian Studies, Vol. 8, No. 3, pp. 473-504. 